\title{
TRENDS IN THE GROWTH OF ICICI MUTUAL FUNDS
}

\author{
* Dr. Rupa Gunaseelan
}

and

** Dr. V. Ramanujam

\section{INTRODUCTION}

A mutual fund is simply a financial intermediary that allows a group of investors to pool their money together with a predetermined investment objective. The mutual fund will have a fund manager who is responsible for investing the pooled money into specific securities (usually stocks or bonds). When you invest in a mutual fund, you are buying shares (or portions) of the mutual fund and become a shareholder of the fund. Mutual funds are one of the best investments ever created because they are very cost efficient and very easy to invest in (you don't have to figure out which stocks or bonds to buy). By pooling money together in a mutual fund, investors can purchase stocks or bonds with much lower trading costs than if they tried to do it on their own. But the biggest advantage to mutual funds is diversification. A Mutual Fund is a trust that pools the savings of a number of investors who share a common financial goal. The money thus collected is then invested in capital market instruments such as shares, debentures and other securities. The income earned through these investments and the capital appreciation realized is shared by its unit holders in proportion to the number of units owned by them. Thus a Mutual Fund is the most suitable investment for the common man as it offers an opportunity to invest in a diversified, professionally managed basket of securities at a relatively low cost.

\section{MUTUAL FUNDS INDUSTRY IN INDIA}

The origin of mutual fund industry in india is with the introduction of the concept of mutual fund by UTI in the year 1963. Though the growth was slow, but it accelerated from the year 1987 when non-UTI players entered the industry. In the past decade, Indian mutual fund industry had seen dramatic improvements, both quality wise as well as quantity wise. Before, the monopoly of the market had seen an ending phase; the Assets Under Management (AUM) was 67Bn Rupees.. The private sector entry to the fund family raised the AUM to 470 bn Rupees in March 1993 and till April 2004, it reached the height of 1,540 bn Rupees. Putting the AUM of the Indian Mutual Funds Industry into comparison, the total of it is less than the deposits of SBI alone, constitute less than 11 percent of the total deposits held by the Indian banking industry. The main reason of its poor growth is that the mutual fund industry in India is new in the country. Large sections of Indian investors are yet to be familiarised with the concept. Hence, it is the prime responsibility of all mutual fund companies, to market the product correctly abreast of selling. The mutual fund industry can be broadly put into four phases according to the development of the sector. Each phase is briefly described as under.

\footnotetext{
* Associate Professor, Bharathiar School of Management and Entrepreneur Development, Bharathiar University, Coimbatore - 46

* Assistant Professor, Bharathiar School of Management and Entrepreneur Development, Bharathiar University, Coimbatore -46
} 


\section{First Phase 1964-87}

An Act of Parliament established Unit Trust of India (UTI) on 1963. It was set up by the Reserve Bank of India and functioned under the Regulatory and administrative control of the Reserve Bank of India. In 1978 UTI was de-linked from the RBI and the Industrial Development Bank of India (IDBI) took over the regulatory and administrative control in place of RBI. The first scheme launched by UTI was Unit Scheme 1964. At the end of 1988 UTI had Rs. 6,700 crores of assets under management.

\section{Second Phase-1987-1993 (Entry of Public Sector funds)}

Entry of non-UTI mutual funds. SBI Mutual Fund was the first followed by Canbank Mutual Fund (December 1987), Punjab National Bank Mutual Fund (Aug 89), Indian Bank Mutual Fund (November 1989), Bank of India (June 1990), Bank of Baroda Mutual Fund (Oct0ber 1992). LIC in 1989 and GIC in 1990. The end of 1993 marked Rs.47,004 as assets under management.

\section{Third Phase- 1993-2003 (Entry of Private Sector Funds)}

With the entry of private sector funds in 1993, a new era started in the Indian mutual fund industry, giving the Indian investors a wider choice of fund families. Also, 1993 was the year in which the first Mutual Fund Regulations came into being, under which all mutual funds, except UTI were to be registered and governed. The erstwhile Kothari Pioneer (now merged with Franklin Templeton) was the first private sector mutual fund registered in July 1993. The 1993 SEBI (Mutual Fund) Regulations were substituted by a more comprehensive and revised Mutual Fund Regulations in 1996. The industry now functions under the SEBI (Mutual Fund) Regulations 1996. The number of mutual fund houses went on increasing, with many foreign mutual funds setting up funds in India and also the industry has witnessed several mergers and acquisitions.
As at the end of January 2003, there were 33 mutual funds with total assets of Rs. 1,21,805 crores. The Unit Trust of India with Rs.44,541 crores of assets under management was way ahead of other mutual funds.

\section{Fourth Phase- Since February 2003}

This phase had bitter experience for UTI. It was bifurcated into two separate entities. One is the Specified Undertaking of the Unit Trust of India with AUM of Rs.29,835 crores (as on January 2003). The Specified Undertaking of Unit Trust of India, functioning under an administrator and under the rules framed by Government of India and does not come under the purview of the Mutual Fund Regulations. The second is the UTI Mutual Fund Ltd, sponsored by SBI, PNB, BOB and LIC. It is registered with $S E B I$ and functions under the Mutual Fund Regulations. With the bifurcation of the erstwhile UTI which had in March 2000 more than Rs.76,000 crores of AUM and with the setting up of a UTI Mutual Fund, conforming to the SEBI Mutual Fund Regulations, and with recent mergers taking place among different private sector funds, the mutual fund industry has entered its current phase of consolidation and growth. As at the end of September 2004, there were 29 funds, which manage assets of Rs.1,53,108 crores under 421 schemes.

\section{MUTUAL FUNDS COMPANIES IN INDIA}

The concept of mutual funds in India dates back to the year 1963. The era between 1963 and 1987 marked the existence of only one Mutual Fund Company in India with $67 \mathrm{Bn}$. Rupees assets under management (AUM), by the end of its monopoly era, the Unit Trust of India (UTI). By the end of the 80 s decade, few other mutual fund companies in India took their position in mutual fund market. The new entries of mutual fund companies in India were SBI Mutual Fund, Canbank Mutual Fund, Punjab National Bank Mutual Fund, Indian Bank Mutual 
Fund, Bank of India Mutual Fund. The succeeding decade showed a new horizon in Indian Mutual Fund industry. By the end of 1993, the total AUM of the industry was $470.04 \mathrm{Bn}$ Rupees. The private sector funds started penetrating the fund families. In the same year the first Mutual Fund Regulations came into existence with re-registering all mutual funds except UTI. The regulations were further given a revised shape in 1996. Kothari Pioneer was the first private sector mutual fund company in India, which has now merged with Franklin Templeton. Just after ten years with private sector player's penetration, the total assets rose up to $1218.05 \mathrm{Bn}$. Rupees. Today there are 33 mutual fund companies in India. There are following major mutual fund companies in India

1. ABN AMBRO Mutual Fund

2. Birla Sun Life Mutual Fund

3. Bank of Baroda Mutua! Fund (BOB Mutual Fund)

4. HDFC Mutual Fund

5. HSBC Mutual Fund

6. ING Vysya Mutual Fund

7. Prudential $\mathrm{IClCl}$ Mutual Fund

8. Sahara Mutual Fund

9. State Bank of India Mutual Fund

10. Tata Mutual Fund

11. Kotak Mahindra Mutual Fund

12. Unit Trust of India Mutual Fund

13. Reliance Mutual Fund

14. Standard Chartered Mutual Fund

15. Franklin Templeton India Mutual Fund

16. Morgan Stanely Mutual Fund India

17. Escorts Mutual Fund

18. Alliance Capital Mutual Fund

19. Benchmark Mutual Fund

20. Canbank Mutual Fund

21. Chola Mutual Fund

22. LIC Mutual Fund

23. GIC Mutual Fund

\section{OBJECTIVES OF THE STUDY}

The Study aims to

Understand the growth of $\mathrm{ICICl}$ Mutual Funds in India.

$>$ Understand the various type of mutual fund plans offered by $\mathrm{ICICI}$ Securities Ltd

$>$ Analyze the trends in the growth of Mutual Fund of $\mathrm{IClCl}$ securities $\mathrm{Ltd}$

\section{METHODOLOGY}

The study is primarily confined to $\mathrm{ICICI}$ Securities Ltd. The study makes use of secondary data related to the required variables. The data were collected from the official websites of ICICI Securities Ltd and NSE (National Stock Exchange). IClCl entered in Mutual Fund industry in 1992. The study collected data on the required variables from 1998 for the purpose of analysis. The $\mathrm{ICICl}$ Securities Ltd promotes a number of Mutual Funds, of which twenty growth funds were chosen at random from their inception into the fund. Therefore the period of study of each fund differ according to their inception. Based on the secondary data, the study made useful analysis with the help of appropriate statistical tools. Simple annual growth rate was applied to estimate the growth NAV of concerned Mutual Funds.

\section{REVIEW OF LITERATURE}

The concept of Mutual Fund being a very sensitive area of financial management, the attention of many small and medium scale investors have started to concentrate on this very sensitive but a volatile area. A number of studies have been conducted and published however briefing such studies will highlight the importance of the present study. Examined the issue of the risk-return relationship on the basis of a study carried out on the performance if Indian Mutual Funds with the help of the data obtained from 77 schemes on an average proved true to their aims and the Growth Schemes yielded an average of 47 percent. Compounded annual return of Tax planning schemes on an average yielded 
30 percent followed by Balanced Schemes with 28 percent and Income Schemes with 18 percent compounded annual returns. ${ }^{1}$

For Mutual Fund analysts, new insights into evaluating a Fund's performance don't come along every day. Lately through, financial experts at Wharton and other schools have collaborated on research that challenges some long held notions about which funds are best for investors. Evaluating Mutual Funds performance, the authors note, requires a combination of data and judgment. The Judgment comes in when picking what standard, or benchmark, to use as the basis for calculating how well a Excellent portfolios can be constructed by owning shares in Indian Funds plus actively managed funds. Such a blended approach fundamentally subscribes to the verdict of financial market theory by accepting indexing as the core component and cornerstone of a portfolio. It also satisfies the seductive instincts and competitive inclinations of that faction of investors whose predictions demand commitment of analytical resources toward the discovery of portfolio managers deemed to have a realistic profitability of delivering market beating returns with a tolerable level of risk. ${ }^{2}$

Results of recent research indicate small investors sentiment as measured by the change in the discount on Closed-end funds, in an important factor in the return generating process for common stocks. We find no evidence of it being an important factor in the return generating process. We next examine its impact on expected returns and whether one set firms with high sensitivity to this factor-Closedend funds- offers, and can be expected to offer, a higher expected return our findings do not support to small investor sentiment as priced factor, either in common stocks or Closed-end funds. ${ }^{3}$

\section{GROWTH NAV OF MUTUAL FUNDS}

The Net Asset Value (NAV) is the appropriate indicator of the growth of a Mutual Fund. In this section a attempt has been made to analyse the various in the growth of Mutual Funds of $\mid \mathrm{ClCl}$ Securities Ltd since their inception. There are following various types of mutual funds provided by $\mathrm{ICICl}$ securities Limited.

1. ICICI Prudential Balanced Fund

2. IClCl Prudential Blended Plan

3. ICICl Prudential Child Care Plan-Gift.

4. ICICI Prudential Child Care Plan-Study

5. ICICI Prudential FMCG Fund

6. ICICI Prudential Gilt Fund-PF option

7. ICICl Prudential Growth Plan

8. ICICI Prudential Income Multiplier Fund

9. ICICI Prudential Income Plan

10. ICICI Prudential Index Fund

11. IClCl Prudential Infrastructure Fund

12. ICICI Prudential Liquid Plan

13. ICICl Prudential Long Term Floating Rate Plan

14. Prudential ICICI Long Term Plan

15. IClCl Prudential Monthly Income Plan

16. ICICI Prudential Services Industries Fund

17. ICICI Prudential Short Term Plan

18. ICICl Prudential Spice Fund

19. Prudential ICICl Sweep Plan

20. ICICl Prudential Technology Fund

1 Kale and Uma "Risk-return relationship on the basis of a study carried out on the Performance of Indian Mutual Fund", May 15, 1995, PP-3, 4

2 Richard kjetsaa "The Performance of Sector Mutual Funds Relative to Benchmarks". Journal of the Academy of Business and Economics. February 2005. FindArticles.com, 23 September 2006.

3 Do Investors Care Sentiment? Edwin J. Elton, Martin J. Gruber, Jeffrey A. Busse, Journal of Business, Vol. 71 , No. 4 , October 1998, PP. 477-500 


\section{TRENDS IN THE GROWTH OF ICICI MUTUAL FUNDS}

In this part discuss with the trends in the growth of $\mathrm{ICICl}$ Prudential Funds and estimate the trend in the growth of a particular fund and use regression function. Norder to estimate the trend in the growth of a particular fund, a regression equation was formulated. The regression equation takes a semi-log function as specified below.

$$
\begin{aligned}
& \ln Y=\alpha+\beta(X)+e \\
& Y=N A V, X=\text { Time }
\end{aligned}
$$

Where, $\alpha=$ Constant, $\beta=$ co-efficient, $e=$ error term

Using ordinary least square method the semi-log function was estimated for all the twenty funds under consideration. The estimated co-efficient "â" represents the relative change in NAV of a fund for an absolute change in the time period. It is thus gives an average annual growth rate of the fund. The table 1 presents the results of estimated equation.

Table 1

\begin{tabular}{|c|c|c|c|c|}
\hline $\begin{array}{l}\text { SI. } \\
\text { No } \\
\end{array}$ & Fund & $(\alpha)$ & $\beta$ & $R^{2}$ \\
\hline 1. & $\mathrm{ICICI}$ Prudential Balanced Fund & 1.89 & $0.827(3.89)^{\star \star}$ & 0.68 \\
\hline 2. & ICICI Prudential Blended Plan & 2.36 & $0.986(18.79)^{\star \star}$ & 0.97 \\
\hline 3. & $\mathrm{ICICI}$ Prudential Child Care-Gift Plan & 2.01 & $0.969(13.83)^{\star \star}$ & 0.94 \\
\hline 4. & ICICI Prudential Child Care-Study Plan & 2.23 & $0.987(54.31)^{* *}$ & 0.97 \\
\hline 5. & ICICI Prudential FMCG Plan & 1.73 & $0.774(5.550)^{* \star}$ & 0.60 \\
\hline 6. & $\mathrm{ICICI}$ Prudential Gilt Fund-PF option & 2.39 & $0.973(13.25)^{\star \star}$ & 0.95 \\
\hline 7. & ICICI Prudential Growth Plan & 2.26 & $0.868(4.63)^{\star \star \star}$ & 0.75 \\
\hline 8. & ICICI Prudential Income Multiplier Plan & 2.56 & $0.910(6.74)^{\star \star}$ & 0.82 \\
\hline 9. & ICICI Prudential Income Plan & 2.34 & $0.950(8.06)^{\star \star}$ & 0.90 \\
\hline 10. & $\mathrm{ICICI}$ Prudential Index Fund & 1.81 & $0.952(6.22)^{\star \star *}$ & 0.90 \\
\hline 11. & $\mathrm{ICICI}$ Prudential Infrastructure Fund & 2.60 & $0.767(3.77)^{\star \star}$ & 0.59 \\
\hline 12. & ICICI Prudential Liquid Plan & 2.57 & $0.724(2.78)^{\star \star *}$ & 0.52 \\
\hline 13. & ICICI Prudential Long Term Floating Rate Plan & 2.38 & $0.990(144.62)^{\star *}$ & 0.99 \\
\hline 14. & ICICI Prudential Long Term Plan & 2.68 & $0.990(63.58)^{\star \star}$ & 0.99 \\
\hline 15. & ICICI Prudential Monthly Income Plan & 2.86 & $0.890(6.16)^{\star \star}$ & 0.79 \\
\hline 16. & ICICI Prudential Service Industries Fund & 2.30 & $0.840(4.84)^{\star \star}$ & 0.70 \\
\hline 17. & ICICI Prudential Short Term Plan & 2.59 & $0.990(80.03)^{\star \star}$ & $0.99^{\prime}$ \\
\hline 18. & ICICI Prudential Spice Fund & 4.68 & $0.810(4.43)^{* *}$ & 0.66 \\
\hline 19. & ICICI Prudential Sweep Plan & 2.31 & $0.990(78.42)^{\star *}$ & 0.99 \\
\hline 20. & ICICI Prudential Technology Fund & 2.24 & $0.840(4.90)^{\star *}$ & 0.71 \\
\hline
\end{tabular}

Estimating Semi-Log Function

Figures in the parenthesis are " $\mathrm{u}^{n}$ value ${ }^{* *}$ Significance at 1 percent Level 
From the table 1 it is noticed that the trend in the growth of all the funds are quite impressive. Though there are slight variations, which range from 72.4 percent in ICICI Prudential Liquid Plan to 99 percent. Long Term Floating Rate Plan, ICICI Prudential Long Term Plan, ICICI Prudential Short Term Plan, $\mathrm{ICICl}$ Prudential Sweep Plan, alone records a comparatively slow growth of 72.4 percent per annum. It is also found that the estimated co-efficient of time was observed statistically significant for all the funds at 1 percent level of significance.

\section{INTER RELATIONSHIP BETWEEN NAV AND NIFTYINDEX}

$\mathrm{IClCl}$ Securities Ltd included S\&P CNXNIFTY Index.

Changes in the NAV of Mutual Funds of $1 \mathrm{ClCl}$ Securities Ltd will alter NIFTY also. Similarly changes in NIFTY do have its impact on the NAV. This theoretical relationship is empirically tested for all the funds under study.

\section{CORRELATION ANALYSIS}

Correlation simply explains the relationship between NAV and NIFTY. This section presents correlation co-efficient " $r$ " estimated separately for the NAV and NIFTY and the same is presented in table 2.

\section{REGRESSION ANALYSIS}

Hence, an attempt has been made to understand the cause and effective relationship between NAV and NIFTY Index. In order to test this relationship empirically, a linear regression model was formulated as specified below.

$$
Y=f(X)
$$

This functional relationship takes following form of equation

$(X)+e$

Where $Y=\alpha+\beta$ NIFTY $\mathrm{Y}=\mathrm{NAV}, \mathrm{X}=$ $\alpha=$ constant, $\beta=$ co-efficient, $e=$ error term. This equation was separately applied for all the twenty funds considered in the study. The estimated equation was presented in the table 3 .

Table 2

Correlation between NAV and NIFTY Index

\begin{tabular}{|c|l|c|}
\hline $\begin{array}{c}\text { SI. } \\
\text { No }\end{array}$ & \multicolumn{1}{|c|}{ Funds } & $\mathbf{r}$ \\
\hline 1. & $\mathrm{ICICI}$ Prudential Balanced Fund & 0.98 \\
\hline 2. & $\mathrm{ICICI}$ Prudential Blended Plan & 0.78 \\
\hline 3. & $\mathrm{ICICI}$ Prudential Child Care-Gift Plan & 0.78 \\
\hline 4. & $\mathrm{ICICI}$ Prudential Child Care-Study Plan & 0.97 \\
\hline 5. & $\mathrm{ICICI}$ Prudential FMCG Plan & 0.93 \\
\hline 6. & $\mathrm{ICICI}$ Prudential Gilt Fund-PF option & 0.79 \\
\hline 7. & $\mathrm{ICICI}$ Prudential Growth Plan & 0.99 \\
\hline 8. & $\mathrm{ICICI}$ Prudential Income Multiplier Plan & 0.76 \\
\hline 9. & $\mathrm{ICICI}$ Prudential Income Plan & 0.89 \\
\hline 10. & $\mathrm{ICICI}$ Prudential Index Fund & 0.69 \\
\hline
\end{tabular}




\begin{tabular}{|c|c|c|}
\hline 11. & $\mathrm{IClCl}$ Prudential Infrastructure Fund & 0.91 \\
\hline 12. & ICICI Prudential Liquid Plan & 0.87 \\
\hline 13. & $\mathrm{IClCl}$ Prudential Long Term Floating Rate Plan & 0.88 \\
\hline 14. & $\mathrm{ICICl}$ Prudential Long Term Plan & 0.86 \\
\hline 15. & $\mathrm{ICICI}$ Prudential Monthly Income Plan & 0.99 \\
\hline 16. & ICICI Prudential Service Industries Fund & 0.95 \\
\hline 17. & ICICl Prudential Short Term Plan & 0.90 \\
\hline 18. & $\mathrm{IClCl}$ Prodential Spice Fund & 0.99 \\
\hline 19. & IClCl Prudential Sweep Plan & 0.98 \\
\hline 20. & ICICI Prudential Technology Fund & 0.77 \\
\hline
\end{tabular}

From the table 2 it could be inferred that there is a strong positive correlation between NAV and NIFTY Index. The Mutual Fund of $\mathrm{ICICl}$ Securities Ltd is closely related to the NIFTY Index even upto 99 percent. Though there is close relationship, all the funds do not behave in a similar way. This is evident as the estimated " $r$ " value varies between 0.77 and 0.99 .

Table 3

Regression Estimates

\begin{tabular}{|c|c|c|c|c|c|}
\hline $\begin{array}{l}\text { SI. } \\
\text { No }\end{array}$ & Fund & $\alpha$ & B & $R^{e}$ & $\begin{array}{l}\text { Prediction of NAV } \\
\text { if NIFTY }=5000 \\
\end{array}$ \\
\hline 1. & $\mathrm{ICICI}$ Prudential Balanced Fund & 8.42 & $0.0060(16.37)^{\star *}$ & 0.96 & 41.32 \\
\hline 2. & ICICI Prudential Blended Plan & 9.09 & $0.0006(3.09)^{\star \star}$ & 0.49 & 11.84 \\
\hline 3. & ICICI Prudential Child Care-Gift Plan & 5.18 & $0.0090(7.02)^{\star \star}$ & 0.83 & 49.89 \\
\hline 4. & ICICIPr' dential Child Care-Study Plan & 12.02 & $0.0020(5.64)^{\star \star}$ & 0.76 & 21.54 \\
\hline 5. & ICICIPr idential FMCG Plan & 12.65 & $0.0071(5.84)^{\star \star}$ & 0.78 & 48.27 \\
\hline 6. & ICICI Prudential Gilt Fund-PF option & 9.68 & $0.0004\langle 5.29)^{\star \star}$ & 0.74 & 11.82 \\
\hline 7. & ICICIPrudential Growth Plan & 5.36 & $0.0220(25.14)^{*+}$ & 0.98 & 115.72 \\
\hline 8. & ICICI Prudential Income Multiplier Plan & 8.20 & $0.0015(9.90)^{\star \star}$ & 0.91 & 15.98 \\
\hline 9. & ICICI Prudential Income Plan & 16.81 & $0.0012(6.70)^{\star \star}$ & 0.82 & 22.76 \\
\hline 10. & $\mathrm{IClCl}$ Prudential Index Fund & -0.53 & $0.0089(41.19)^{\star \star *}$ & 0.99 & 44.47 \\
\hline 11. & $\mathrm{ICICI}$ Prudential Infrastructure Fund & -4.97 & $0.0059(18.58)^{* *}$ & 0.98 & 24.51 \\
\hline 12. & IClCI Prudential Liquid Plan & 14.947 & $0.0007(3.82)^{\star \star}$ & 0.59 & 14.95 \\
\hline 13. & $\mathrm{IClCl}$ Prudential Long Term Floating Rate Plan & 9.43 & $0.0005(3.94)^{\star *}$ & 0.61 & 11.85 \\
\hline 14. & ICICI Prudential Long Term Plan & 12.64 & $0.0007(3.91)^{\star \star}$ & 0.60 & 16.12 \\
\hline 15. & ICICI Prudential Monthly Income Plan & 13.05 & $0.0015(12.32)^{\star \star *}$ & 0.94 & 20.45 \\
\hline
\end{tabular}




\begin{tabular}{|c|c|c|c|c|c|}
\hline $\begin{array}{l}\text { SI. } \\
\text { No }\end{array}$ & Fund & $\alpha$ & B & $\boldsymbol{R}$ & $\begin{array}{c}\text { Prediction of NAV } \\
\text { if NIFTY }=5000 \\
\end{array}$ \\
\hline 16. & ICICI Prudential Service Industries Fund & -7.41 & $0.0057(8.05)^{\star *}$ & 0.87 & 20.86 \\
\hline 17. & IClCI Prudential Short Term Plan & 11.53 & $0.0006(4.08)^{\star \star}$ & 0.62 & 14.67 \\
\hline 18. & $\mathrm{ICICI}$ Prudential Spice Fund & -9.51 & $0.0377(28.72)^{\star \star}$ & 0.99 & 179.39 \\
\hline 19. & ICICl Prudential Sweep Plan & 8.66 & $0.0005(3.80)^{\star \star}$ & 0.59 & 11.10 \\
\hline 20. & ICICI Prudential Technology Fund & -9.48 & $0.0061(6.35)^{\star \star}$ & 0.80 & 21.33 \\
\hline
\end{tabular}

Figures in the parenthesis are " $\mathrm{t}$ " values

** Significant at 1 percent level

From the table 3, it is could be observed that the change in NIFTY affect the NAV of a fund significantly. The "â" co-efficient in all the equation was found statistically significant at 1 percent level of significance. The independent co-efficient "â" explains the absolute change in the NIFTY Index. The collective influence of the formulated equation is explained by " $R^{2 n}$ value. The estimated " $R^{2 n}$ values are also presented in the table 4.3. The " ${ }^{2 \text { " value }}$ of the equation explained that the change in NIFTY influences the NAV of a fund to the extent of 99 percent in the case of $\mathrm{IClCl}$ Prudential Index Fund and $\mathrm{IClCl}$ Prudential Spice Fund. All other funds have the impact of change in NIFTY to the extent of more than 60 percent except $\mathrm{ICICl}$ Prudential Blended Plan where the impact of NIFTY on its NAV is 49 percent. In spite of this wide fluctuations, since majority of the funds have a collective influence of the NIFTY over 75 percent, it may be concluded that NIFTY influence NAV of a fund significantly.

\section{FINDINGS AND CONCLUSION}

\section{FINDINGS}

In present study estimated the growth of selected Mutual Funds of $\mathrm{ICICl}$ Securities $\mathrm{Ltd}$. The important findings of the study are presented below. i. The growth of NAV of the funds considered in the study is also estimated using a semi$\log$ function. The trend growth of the fund varied between 72.4 percent and 99 percent. It is also found that the estimated time trend was found significant at 1 percent level of significance.

ii. The inter relationship between NAV of the fund and NIFTY Index was also estimated. The observed correlation co-efficient " $r$ " was 0.99 percent in many cases showing a close positive association between NAV of a fund and NIFTY Index.

iii. The regression estimates of the impact of NIFTY Index on NAV was also studied with the help of regression analysis. The estimated co-efficient in determining the NAV.

iv. The forecasting of NAV of each fund has also attempted with the assumption of NIFTY to be 5000 


\section{CONCLUSION}

The present study estimated the trends in the growth of Net Asset value of twenty selected Mutual funds schemes of $\mathrm{ICICI}$ Securities $\mathrm{Ltd}$. The analysis made to estimate the growth and to find the inter relationship between NAV and NIFTY Index are important measure for making investment decision. Similarly the study also found the significant influence of the changes in NIFTY Index on the Net Asset Value of different Mutual Funds scheme of $\mathrm{IClCl}$ securities $\mathrm{Ltd}$. The forecasting model framed on the basis of the significant linear relationship between NIFTY and NAV will be a guiding tool to the investors.

\section{REFERENCES}

Bhole, L.M. 'FINANCIAL INSTITUTIONS AND FUTURES MARKET Tata MCGraw Hill Edition, $3^{\text {rd }}$ edition, New Delhi

Donald R. Cooper Pamela S. Schindler 'BUSINESS RESEARCHMETHODS' Tata McGraw-Hill Edition, $8^{\text {th }}$ Edition, New Delhi.

Kotler Philip 'MARKETING MANAGEMENT

Prentice Hall Private Ltd, $10^{\text {th }}$ Edition, New

Delhi.AMFIINVESTS INDIA Hand Book.

Kothari. C.R. 'RESEARCHMETHODOLOGY' Wishwa Prakasham, Second Edition, New Delhi.
Kale and Uma "Risk-return relationship on the basis of a study carried out on the Performance of Indian Mutual Fund", May 15, 1995

Richard kjetsaa, Journal of the Academy of Business and Economics. February 2005. FindArticles.com, 23 September 2006.

Edwin J. Elton, Martin J. Gruber, Jeffrey A. Busse, Journal of Business, Vol. 71, No. 4 , October 1998

\section{WEBSITES}

www.amfiindia.com

uww.icicipruamc.com.

www.icicidirect.com

www.icicibank.com

uww.moneycontrol.com

unw.mutualfundsindia.com

umw.principalindia.com 